\title{
The Modernist Worlds of Catalá and Ruelas ${ }^{1}$
}

\author{
Rosario Faraudo \\ Universidad Nacional Autonoma de México
}

$\mathrm{L}$

iterary tradition identifies the Latin American modernist movement with the renewal of language in literature which developed in the area late in the XIX century. It is not exactly equivalent to European modernism, but is more related to symbolism and fin-de-siecle decadentism. As a matter of fact, the Mexican poets who first embraced this current initially called it «decadentism.» The term

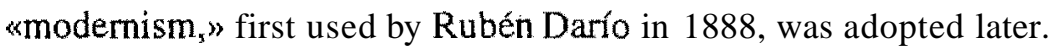

The group of Mexican modernists was formed mainly by poets who found in the Revista Modema a vehicle for the publication of their work. They shared not only an interest in the value of language itself, regardless of its referential aspect, but also the pessimism and ennui that set in with the turn 'of the century. This was true of their art as well as of their lives. Most of these men sought to balance their anguish and disgust for life by indulging the senses, which led to all kinds of excess: alcohol, drugs, sexual experimentation, and the consequent diseases.

Julio Ruelas (1870-1907), a painter and draftsman born in Zacatecas, was part of this group. He illustrated many of the poems published by the modernist poets, his imagination frequently reached beyond that of the poets, blurring the boundaries between text and image. His affinity with the poets led Alfonso Reyes to consider Ruelas «a literary painter,» in whose art the somber sensual inclinations of the modernists could be found (Del Conde 1976,23). Ida Rodríguez PrampoJini refers to him as «a brother to Baudelaire and the 'poetes maudits'» (92).

One needn't read about Ruelas' professed hatred of women to perceive that

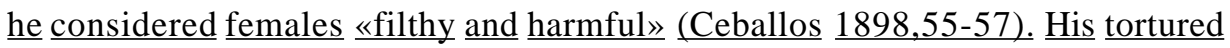


imagination was the perfect match to the pessimism pervading the work of his peers, as well as a strong reflection of the fin-de-siecle misoginy identified by B. Dijkstra (1986) in European art and literature of the same period.

Ruelas remained outside the pictorial currents followed by his Mexican contemporaries. His temperament was more sui ted to the European sy mbolist mode of expression, which he adopted. The artist spent a few years studying in Germany (18921895 ) and was strongly influenced by his European contemporaries. Later on (1904), he returned to Europe. this time to Paris. where he died in 1907. Germanic an and culture are present in Ruelas work- from Hans Baldung Grien (Figure I) and Durer. to hi s contemporaries Franz von Stuck (Figure 2) and Max Klinger, who shared with him the repeated ponrayal of women's bestial proclivities.

Across the Atlantic, Victor CatalA (Caterina Alben, 1869-1966), a Catalonian prose writer and

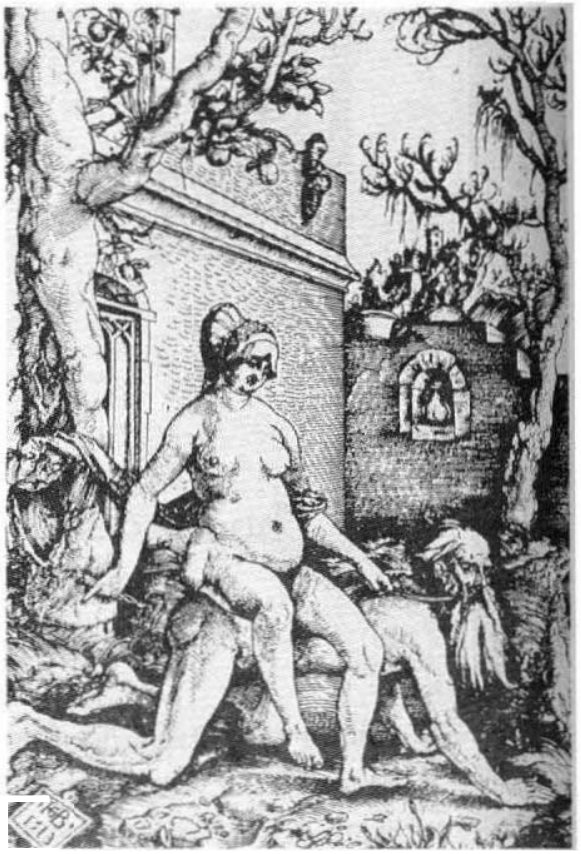

Figure t:Aristóteles, by Hans Baldung Gnen $(\mathrm{t} 513)$ poet, shared some of the main traits of the Latin American modernists. Alan Yate (1969.54) finds many characteristics that link Latin American and Catalan «modernisme»: the need for renovation, a concern with language, the use of symbolism to discover hidden poetical relationships between inner realities and the outside world, a pessimistic view of life and a frank, sometimes even crude, expression of previously forbidden subjects.

The writers of the modernist current in Mexico distanced themselves from the Mexican themes exploited by their romantic predece sors; whereas in Cataloni a the modernists strove to consolidate a renewal of their own language and national identity One of (he vehicles they used was the «rural» novel, of which Victor CatalA was one of the foremost representatives. The themes and aesthetical concerns of the romantic agony found intense expression in some of these modernist novels, such as Solitud (Catal A 1904). This form of «ruralism» is

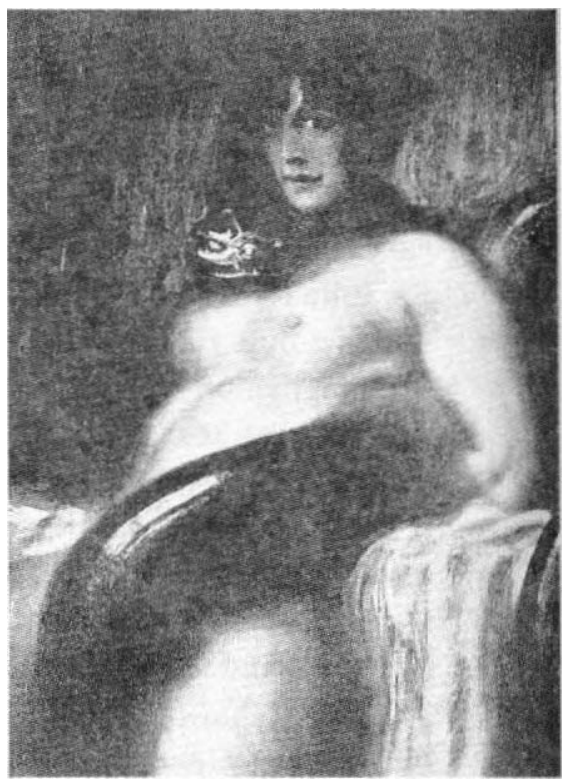

Figure 2: Sensuality, by Sluek (1897) 
related to the «second wave» of naturalism and contains a conspicuous rejection of the false identification between naturalism and romantically conceived Nature (Yates 1975, 80-88).

The rural novel tended to present the dark side of the peasant's life, who is a victim of Nature and its cosmic forces that opress and often annihilate him. This is, in synthesis, Catalá's attitude to hèr subject in her short stories as well as in her novel, Solitud.

Though not a political feminist, the isolation of women is evident in most of her works. As Teresa Vilar6s very accurately points out, «death or violence [is] the common narrative irruption in their lives» $(1993,16)$. Catala's women are sometimes capable of violence, as in «La infanticida,» where a woman kills her infant out of misery, desperation and social pressure. However, a more pervading trait in her work is the inadequacy, the «wants» of most of her male characters, and their consequences for women.

Catalá spent most of her life in Barcelona and in her native L'Escala on the Catalonian coast. Nevertheless, she was obviously in touch with the main literary and philosophical currents of her time, many of whose representativas inspired the Catalan modernists. Among them were Carlyle, Ruskin, Nietszche, Ibsen, and Maeterlink.

Evidentiy, Catalá was not a stranger to the strQng fear of females that pervaded the Europe of her time, and which found a way to the art and writing of the period. In Solitud she acknowledges this atmosphere on two levels. One is the level of the main narrative, where the.heroine is caught in an isolated hermitage, between an inefficient husband-both sexually and economically-and a predator who h;lfks in the mountain until he can safely rape her. Even San Ponç, the patron saint of the hennitage is describes as grotesque. $\mathrm{MBa}$, the heroine is disturbed by his aridroginous image, with a big belly «like that of a fat woman»and a crooked foot which she identified with her husband's tobacco pouch when it was empty-an image with negative sexual connotations.

Gaieta, the kind, old shepherd is the woman's only human support and her guide in her wanderings through the mountain, which in turn will lead her to an awakened consciousness.

In contrast to the husband and the prowler, whose language is quite inarticulate, the shepherd is a gifted narrator. His discourse is the voice of patriarchy itself, advocating faith in prayer and acceptance of prevailing conditions. Catala uses the shepherd's narrative to insert a series of fantastic legends about the mountains where men are either the yictims of women or undergo some kind of violence on their account. These stories stress the identification of women with untamed Nature, and particularly with animals. At the same time, these legends add a mythic dimension to the narrative and characterize the shepherd. Even 
though he is sympathetic to the heroine and worships the memory of his dead wife, the author allows the pervading misoginy of the time to filter into his discourse. Although the description of the "real» world in CatalA evoques somber symbolist landscapes-Jordi Castellan os relates them to Whistler (1982, 4849)- the iconology within the embedded narration of the shepherd has a striking connection to the work of Ruelas.

In Ruelas, women are related to death, tonure or animals, but his animals are usually predators -spiders, bats, ravens, snakes or scorpions. The female vampire first evoqued by Baudelaire and later by a host of XIX century poets and painters, seems to personify the threat of excessive lust that haunted the «vinuous" male of the period and brought out the beast in him. We can find the roots of this attitude as far back as the early Christian writers, such as Jerome, who wrote that «it is not the harlot or adulteress who is spoken of; but woman's love in general is acc used of being ever insati able» (Miles 1991, 154).

Discussing the meaning of women's nakedness in the Christian West, Margaret Miles (155) notes that there are three maj or rhetorical and pictori al devices which contribute to grotesque presentation: caricature, in version and hybridization. Ruelas' feminine monsters constitute a clear example of the latter. Miles also mentions that «in theological and medical di scourse, as well as in the popular arts of the Christian West, the breasts, vagina and uterus have frequently been object of caricature, in both explicit and coven ways.» Miles refers to the work of analysts of the grotesque, such as Bakhtin, Kayser and Harpham who fai 1 to notice the gender assumptions embedded in grotesque art (155).

In $« \mathrm{El}$ reposo del trovador (Figure 3 ) the female vampire is huge, dark and

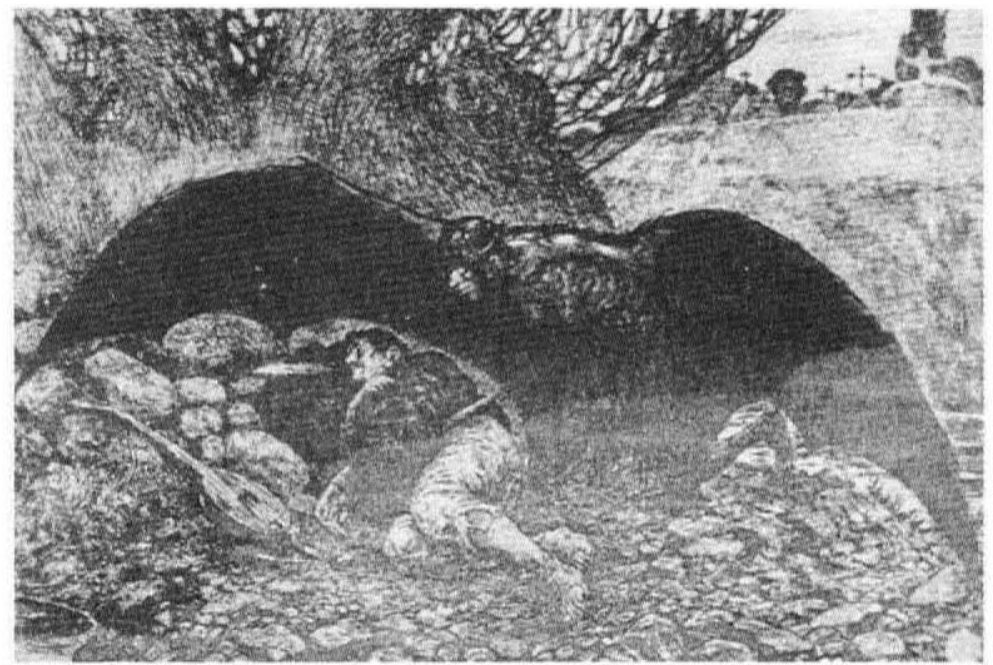

Figure 3: £1 reposo delrrovador. by Ruelas (19061 1907) sini ster, with two long, hanging breasts and a ravenou face. The tree in the background suggests spider webs. and behind it there is a cemetery. Bats wi th hanging breasts appear repeatedly in the work of Ruelas, thus equating them with decrepit and menacing femininity.

Analogy of women to birds and other animals is also one of the features of the tales 
embedded in Solillld. In one of those, the Lord of Lli quens carries a young girl to his castle, rapes her and sends her away. She curses him: «You have treated me like a beast. like a beast I shall see you before my death.» Years later, while he is hunting, she takes revenge. Appearing first as a mountain goat, she lures him up the mountain, and when he is utterly exhausted, his body undergoes a gradual metamorphosis until he becomes a huge black bird. Perched on a tree, he witnesses the death rites of a nun, who is no other than the girl who had cursed him. He then understands he is being punished for his sins and begs for mercy. After being restored to his human form he embraces a life of penitence.

Although in this instance it was a man who had committed a sin, yet it is the woman whose vengeance he suffers and she achieve it by taking animal forms herself and imposing such transformation on her victim.

The relationship of sex with violence continues in other legends, uch as one that explains the reddish color of a waterfall. This is said to be caused by the blood of the women the moor king beheaded after he got tired of them. A remarkable parallel may be found in Ruelas' illustration of a poem by Albeno !tuane, where the dead bodies of her rejected lovers chase a countess along the waters of the Rhine (Figure 4). In both scene, the identification of women with Nature. especially with water, is remarkable.

The longest tale tells of a saintly old man, who had never had any dealings with women-which of course added to his sanctity. He was so innocent, he wore no clothes but covered his body with his very long hair. The other men inhabiting the mountain could not live up to such vinue and gradually abandoned the place. This angered the forest fairies, who thefore decided to take revenge. Floridalba, the youngest, announced she would

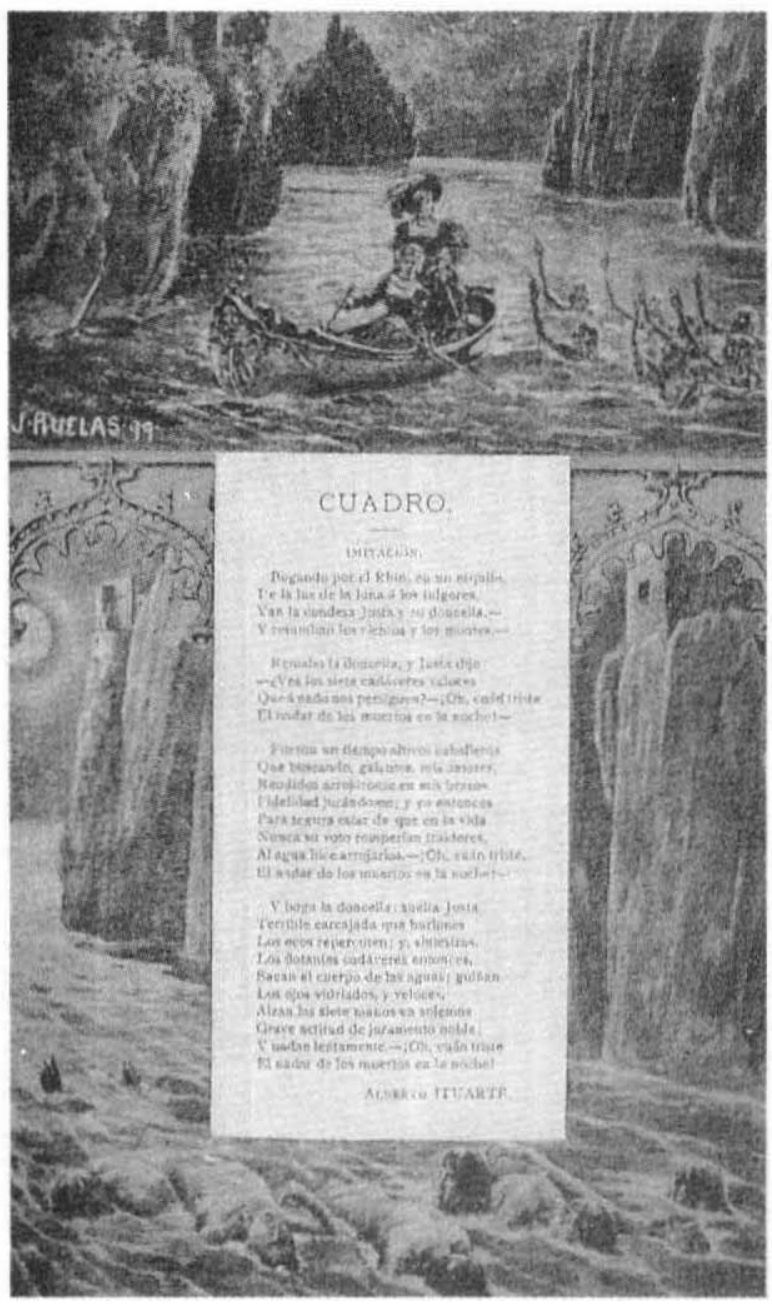

Figure 4: Ruelas' illustration of a poem by huarte (1899) 
undertake the task of making the holy man fall. This recalls the temptation of Saint Anthony by Flaubert as well as the many pictorial representations where the saint is practically mobbed by beautiful nymphs.

The enchantress repeatedly appears to the old man in the shape of a golden bird with three red feathers (for passion) on its head. After the bird's second visit the old man becomes so obse sed with it that he tops praying, eating or sleeping. Finally the holy man sets a trap to «catch» the bird, casting a string arou nd its neck, not knowing that it is he who is being caught. Floridalba then shows herself in beautiful nakedness, wearing around her neck a wreath of roses which falls all the way to the floor. These. are of course the flowers of desire, previously subverted by Baudelaire. The old man is startled and, recalling Adam, covers his body wi th his hair and his face wi th his hands, but still he keeps seeing the woman .

At this point one can hardly help noticing the opposite connotations bestowed on these two naked bodies. The man's nakedness is innocent, unspoiled; the woman's emanates sensuality and temptation. Since the day s of early Chri stianity female nakedness has been used as a cipher for $\sin$, sex and death, and perhaps it should not surprise $\mathrm{u}$ that such attitude toward women' bodies have shown continuity across the centuries.

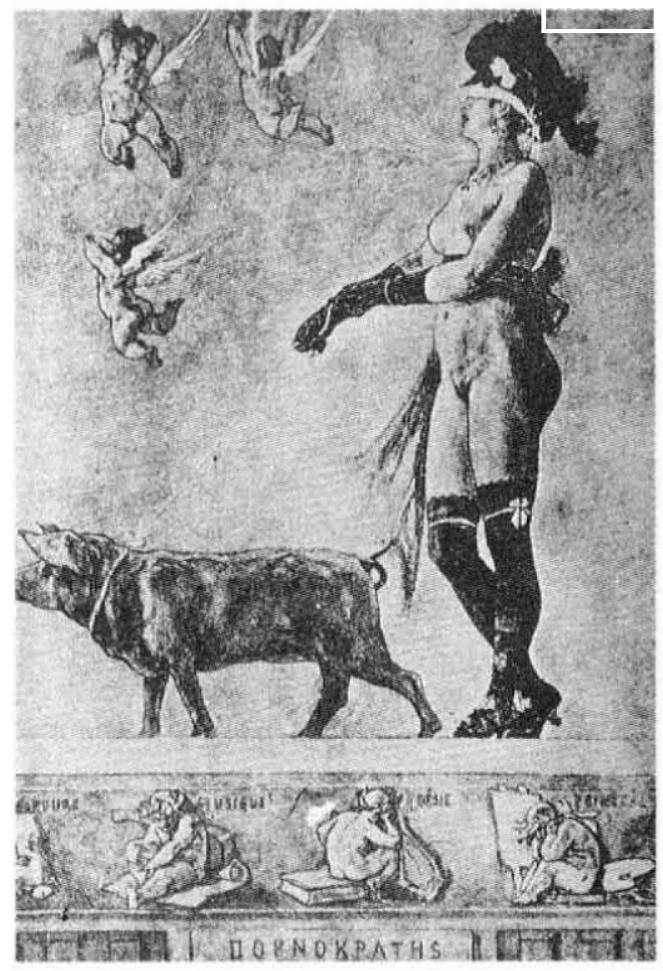

Figure 5: Pornokrates, by Rops ( 1897)
When the naked woman wears some kind of ornament her erotic power increa es, she becomes more enticing. In this regard, it is interesting to observe the parallel between Felicien Rops' «Pornokrates" (Figure 5\}---a naked woman wearing shoes, stockings and a hat, who is being led by a hog, «the sy mbol of Circe, the bestial representative of all sexual evil» (Dfjkstra 324); and Ruelas' «La domadora»-«The Tamer» (Figure 6). In Ruelas' piclUre> the woman wears boots, stockings and a hat, but she has a Whip in her hand and is watChing a hog running with a monkey on its back. Considering Ruelas' taste for the classics, the connection with the myth of Circe is clear. Justino Fernandez (Del Conde 42) reads this picture as an allegory of Ruelas' concept of heterosex ual re lations-sex is evil, it transforms man into a dirty, lascivious animal and woman is the cause. Like Circe, she tempts men only to punish them afterwards. 
Such is the case in our story. Following the pattern of many typical folk tales, Floridalba tempts the holy man first with wealth and next with power. The third temptation is knowledge but, unlike Eve, the saint appeals to God and sends the temptress away. However, she doesn't give up easily, so before disappearing she gives him a farewell kiss. He loses his self.control completely and spends the rest of his days

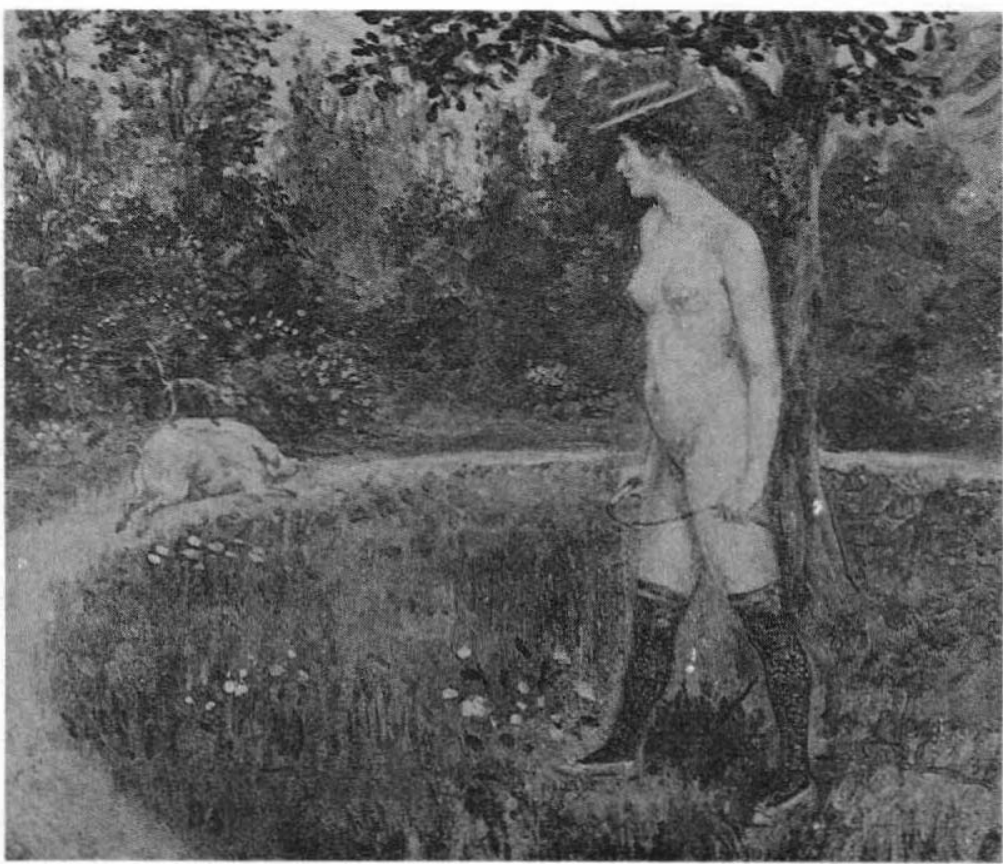

Figure 6: La domadora, by Ruelas (1897) begging her to return, raving that for another kiss he would forego the glory of heaven. Meanwhile Floridalba returns to her comrades, who, incidentally, are knitting, and tells them the good news. Her words stress feminine vanity, for she bades them throwaway their knitting, take their diamond combs and moon light mirrors, magic neclaces, embroidered gowns and satin slippers, for «the men are coming back» (108). The fairies are delighted, since they are certain that the men who have left the mountain out of shame will return as soon as they hear of the hermit's sin.

At the end of her tale Floridalba remarks that since the world began, nobody has found a draught, chain, or spell which is as powerful on men, no matter how saintly, as a woman's kiss.

The old man dies wi thout repentance, is therefore denied entrance to paradise and his soul still wanders about the mountains, while the fairies keep mocking him all over the mountain.

There are several pictures by Ruelas which could fit the ideology of this story. A vignette Showing a naked woman riding an old Socrates (Figure 7) suggests ubmis ion of the intellect to gross passion-also a medieval concern. Even though animal feature s do not appear, the grotesque is achieved by portraying the man acting and being abused like an animal. There is a close connection between this and the Grien picture (Figure I) mentioned previously. The same principle 


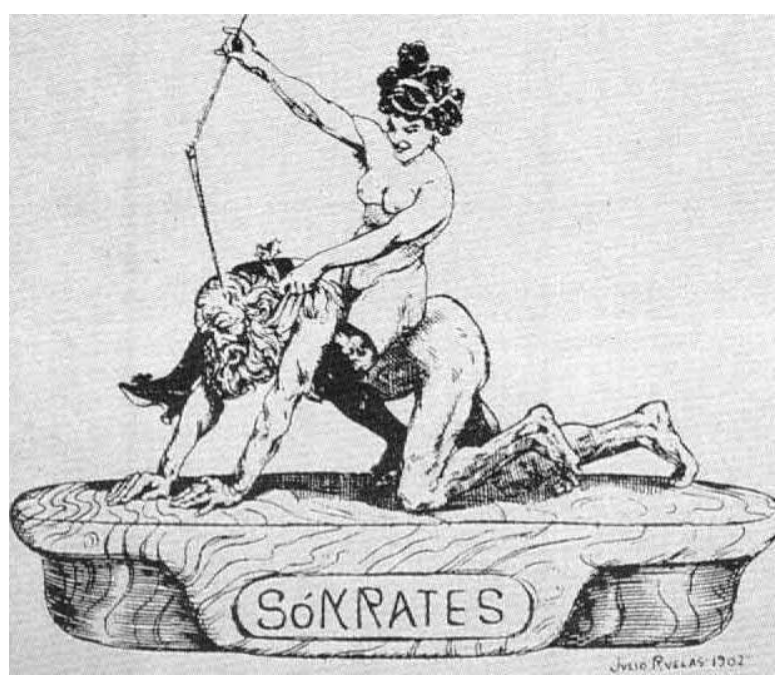

Figure 7: Socrates, by Ruelas (1902) operates in Ruelas' last painting-«The Spider» (Figure 8). It represents a woman silting on her spider-web, gazing at the remains of the man she has lured and destroyed.

Hybridization is used in an etching that shows a man nailed to a cross, whose face resembles the painter's, and is being embraced by a scorpion-woman. In the background there is a suggesti on of the man's soul descending headfirst, with a crown of stars already falling from his head. The man on the cross may be Everyman reaching toward the monster with his free hand. Even

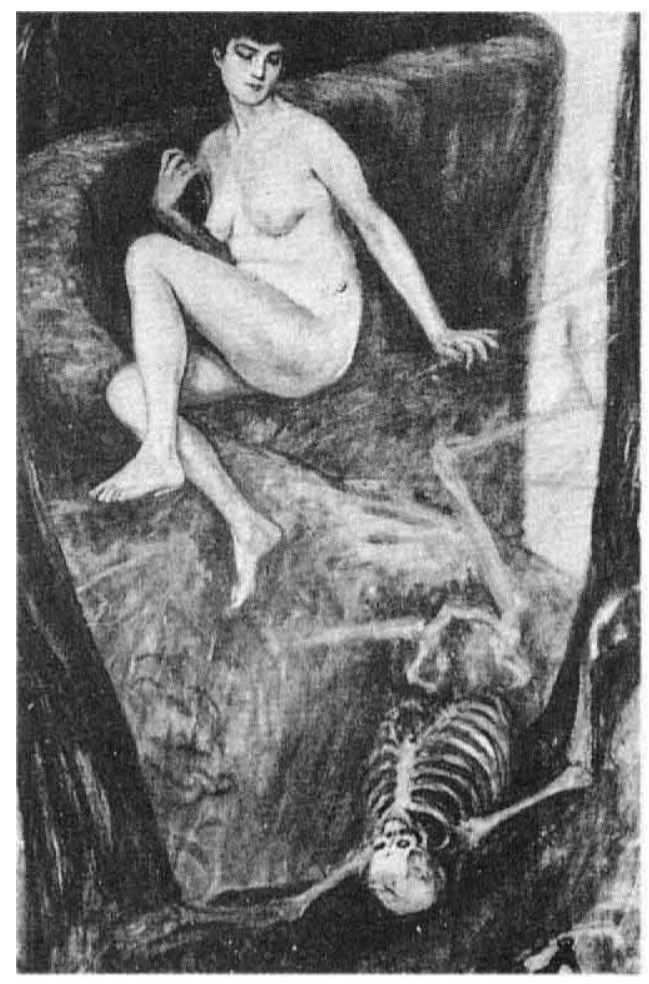

Figure 8: La araiJa, by Ruelas (1907) though the scorpion's «anns» seem to be embracing the man. her claws imply more of an enthralment (Figure 9).

[n the shepherd's legends, as i have already mentioned, the narrator relates women to animals and to Nature in general, mainly forests and water. However, on the firsl narrati ve level, it is the men who are characterized by means of animal features. Anima, the predator. is repeatedly described in animal terms- his forehead «does not lock like a per ons's, » his hands are covered by dark hair and his teeth remind Mila of her uncle's dog. His eyes are those of a wolf and he is referred to as «vermin.» He usually appears unexpectedly, like an animal watching for his prey. Anima's main feature however. is his inarticulate di scourse.

MatIas, the heroine's husband, has animal characteristics as well, since his eyes have no expression. they are «like the eyes of an animal,» but an abnormal animal, '〈puix era una bestia sense zel . ) >--" an animal with no 
heat»(Catala 113). The (,animalizatioo» in MatIas increases as he is tempted by Anima into trapping and gambling, a reversal of the usual temptation normally embodied by women.

Since women have repeatedly been related to $\mathrm{Na}$ ture, it may not be a coincidence that the natural world in Ruelas is barren. The trees he paints are usually dry, and their branche contain more spider webs than leaves. He very frequently uses hybridization in relation to feminity, which links him to the general altitude of his time; sphynx, sirens. serpents, cats and vampires abound in late XIX century European art (Figure 10). Catala uses a similar narrative strategy in defining some of hercharacters, yet with a different orientation.

The author allows the atmosphere of the «Decadence» to show through the shepherd's discour e, in spite of his kindness. However, her own narralive voice

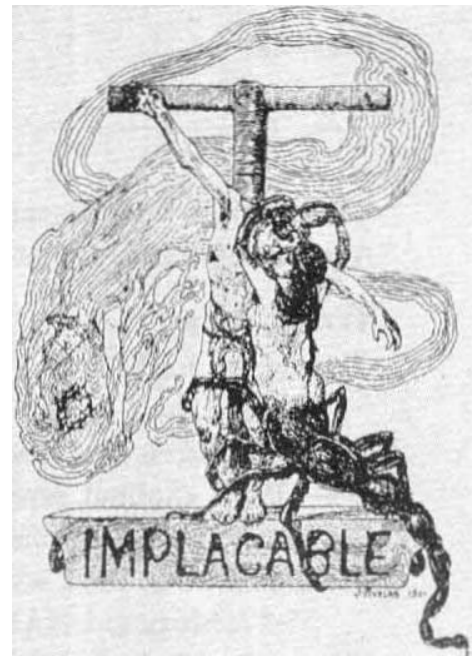

Figure 9 Ilustración para un poema de Amado Nervo, by Ruelas (1901) reverses the principles by which misoginy characterizes women. Her main plot shows the growth of the woman as well as the decline of the husband. She u es hybridization in ponrayingsome of her male character, who range from unreliable and lazy to greedy. cunning and lustful. The shepherd. who is the only positive male character disappears before the end of the novel. when he is no longer necessary. Gaieta is killed by lhe villain, which allows the lalter 10 rape

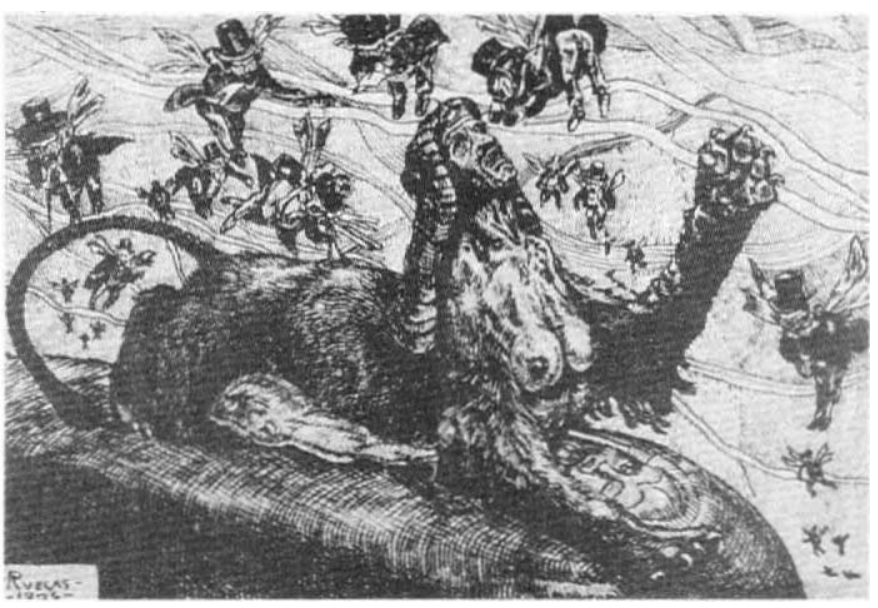

Figure 10: La Esfinge, by Ruelas (1906) lhe unprotected heroine. This completes the proce s of her awakening and hastens her resolution to abandon lhe place as well as her husband. Gi ven Mila's affection for the shepherd and his patriarcal admonitions, hi s presence would have rendered such a decision impossible.

The common narrative slrategies are evidence of the shared cultural atmosphere that marked the tum of the century. regardless of language and nalional barriers. Neverthele $\mathrm{s}$, there is evidence of gender oriented perspectives in V,ctor 
Catalá, where Caterina Albert may be detected behind the mask of her masculine persona.

\section{Nota}

I Este trabajo fue presentado en el Congreso de la American Comparative Literature Association, efectuado en Puerto Vallarta. México, del 10 al 13 de abril de 1997.

\section{Works cited}

Castellanos, Jordi. 1992. «Vfctor Catală i el modernisme.» Acres de las primerasjornades d'estudi sabre la vida y obre de Caterina Alberti Paradis'Victor Catalá. L'Escala. Publicacions de l'Abadfa de Montserrat. 9-11 abri!. 17-41.

—. 1982. «Solitud, novel.la modernista.» Eis Marges 25: 45-70.

Catala, Victor. 1951. Solitud. Obres Completes. Barcelona: Editorial Selecta.

Ceballos, Ciro B. 1987. «Seis apologIas. Julio Ruelas.» Revista Moderna 15 (Sept. 1898): 55-57. México: UNAM.

Chaves, José Ricardo. 1997. Los hijos de Cibeles. Cultura y sexualidad en la literatura de fin del siglo XlX. Instituto de Investigaciones Filol6gicas. México: UNAM.

Del Conde. Teresa. 1976. Julio Ruelas. Instituto de Investigaciones Esteticas. México: UNAM.

Dijkstra, Brarn. 1986. Idols of Perversity: Fantasies of Feminine Evil in Fin-de-Siicle Culture. New York: Oxford UP.

Fernández, Justino. 1983. El arte del siglo XIX en México. Instituto de Investigaciones Esteticas. Mexico: UNAM.

Miles, Margaret. 1991. Carnal Knowing: Female Nakedness and Religious Meaning in the Christian West. New York: Vintage.

Valdés, Héctor, 1987. «México en 1898. Estudio introductorio para la edici6n facsimilar.» Revista Modema 1898-1903. México: UNAM.

Vilar6s, Teresa. 1993. «Caterina Albert i Paradis 'VictorCatala' (1869-1966).» Spanish Women Writers, a Bibliographical Source Book. Eds. Linda Gould, Ellen Engelson, and GloriaFeiman. Westport: Greenwood Press. 12-19.

Yates, Alan. 1975.l)na generació sense novel.La? Barcelona: Edici6ns 62.

1969. «Solitud i els drames rurals.» Serra d'Gr Sept. 54-56. 